\title{
Komunitas Lokal Perspektif HAM dan Hukum Nasional
}

\author{
Jawahir Thontowi
}

There is no a specific term relating to the nation of a local community in Intemational Law. In term of practical meaning, however, the word of indigineous people in intemational convention obviously indicates to the existing of Indonesian societies, such as Badui, Dayak, Asmat, and Kubu. Inspite of the fact, that the local communities are not identical with legal concept of indigineous people in international convention, the 1945 constitution and the anuthonomy of local government Act No. 32/2005, recognize the term of traditional socities or local customary rules. These are relevant element of indigineous people, but they cannot directly be addressed to name local community. This is not because all local communities in indonesia are applied modern type of govermments, but also because traditional values partly operate in certain local communifties. In order awamess of law and human rights, it is relevant to take into account local communities and its interest to accommodate into local law enacted by the local perliement.

Kata kunci: budaya lokal, HAM dan hukum nasional

T ulisan ini dimaksudkan sebagai upaya melihat seberapa jauh peran dan fungsi komunitas lokal dapat menjadi fasilitator bagi terbentuknya suatu kesadaran hukum dan hak asasi manusia. Istilah komunitas lokal dan juga kearifan lokal seringkali terdengar dalam wacana pembangunan demokrasi. Namun, modernitas yang tengah berjalan tidak secara langsung dapat meninggalkan identitas keasliannya. Di satu pihak, peran negara melalui unifikasi hukum diharapkan adanya suatu model penerapan hukum yang efisien dan efektif sehingga kesadaran hukum masyarakat dapat terbentuk secara seragam

Di pihak lain, pengakuan negara terhadap kemajemukan nilai historis, budaya, hukum dan keagamaan dalam masyarakat dengan kesatuan geologis dan geneologis dalam tataran hukum lokat/adat memungkinkan adanya kemajemukan. Perlindungan secara hukum dan HAM atas kemajemukan tersebut terkait dengan nilainilai dan norma-norma lokal dan institusinya merupakan keniscayaan. Komunitas lokal tidak berarti sekedar kelompokmasyarakat tertinggal, melainkan juga keberadaan wilayah-wilayah yang secara kultural dan geografis masih memelihara nilai-nilai tradisional yang masih relevan dengan kehidupan saat ini.

Realitas menunjukkan adanya kemajukan tersebut menimbulkan implikasi atas kontroversi kepentingan antara masyarakat "the people" dan negara atau "the state". Kontroversi tersebut dewasa ini menjadi sangat potensial dalam mendorong terjadinya perubahan. Sehingga perbedaan itu tidak harus dikesampingkan, melainkan dapat diharmonisasi sedemikian rupa. Karena itu, komunitas lokal dalam 
konteks ini tidak sekedar dimaknai oleh batas teritorial atau derajat tradisionalitasnya, melainkan lebih pada sekelompok masyarakat yang hidup dalam suatu wilayah dengan disertai nilai-nilai modernitas. Namun, di sebagian tempat, nilai-nilai dan kearifan lokal masih dipraktikkan.

Pada masa orde baru, pola kenegaraan lebih menunjukkan pada tuntutan mono-loyalitas, terutama bagi Pegawai Negeri Sipil (PNS) dan militer, kebebasan memilih, berserikat, mengemukakan pendapat amat terbatas. Saat ini, kemajemukan dikembangkan dan dilindungi, sehingga model pemerintahan di tingkat kabupaten terdiri dari kecamatan, pedesaan atau kelurahan dapat muncul beraneka ragam. Situasi tersebut tentu saja sangat dipengaruhi oleh kondisi negara yang menaruh kepedulian untuk menghormati dan menjunjung tinggi hak-hak dasar manusia (the fundamental and principle of Human Rights).

Lebih dari satu dasa warsa, kemauan politik pemeritnah Indonesia semakin jelas dan konkret. Sehingga bukti kepedulian pemerintah Indonesia terhadap HAM bukan saja terlihat melalui upaya-upaya meningkatkan jumlah ratifikasi terhadap konsvensikonvensi hukum internasional entang HAM. Melainkan juga telah ditindaklanjuti dengan mendirikan berbagai institusi yang otoritatif dalam proses penegakan HAM. Direktorat Jenderal HAM adalah bukti institusi yang secara langsung berada dalam Departemen Kehakiman RI atau saat ini Departemen Hukum dan HAM RI.

Tugas Dirjen HAM dalam konteks harmonisasi yaitu melakukan upaya bagaimana ketiga sistem yaitu global, nasional, dan lokal dapat diakomodir dalam menuju masyarakat demokratis yang lebih baik (Lihat dalam gambar No.1)

'Lihat hasil kajian Theodore Collumbis, dalam International Relations and Politics. 1982 
pemerintah. Sehingga pemerintah di berbagai negara, termasuk Indonesia tidak terkecuali menjadi niscaya untuk mengangkat dan mempromosikan HAM universal dengan mencoba melakukan harmonisasi secara gradual.

Bagaimanakah cara agar komunitas lokal mampu memberikan kontribusinya terhadap upaya meningkatkan kualitas kesadaran hukum dan kesadaran akan niliai-nlai universal HAM? Dalam tataran pertama, kesadaran hukum dan HAM pada masyarakat terkait dengan perlunya upaya melakukan sosialisasi atau edukasi tentang norma hukum dan nila-nilai HAM. Proses pendidikan baik formal non-formal, terstruktur atau tidak, proses prilaku individu dan masyarakat akan dipengaruhi.keinginan masyarakat untuk menerapkan kepatuhan atas hukum dan HAM tersebut akan semakin tampak. Tanpa adanya upaya yang bersifat gradual antara nilai-nilai universal, nasional, dan lokal dalam satu sistem terpadu sesuai dengan kemampuan dan kapasitas masing-masing.

Ada beberapa cara yang harus ditempuh dalam membangun kesadaran hukum masyarakat melalui pemberdayaan komunitas lokal. Pertama, menetapkan status hukum (legalstanding) komunitas lokal atau institusi adat, baik dalam sistem hukum internasional maupun dalam sistem pemerintahan Rl. Kedua, bagaimana upaya yang harus ditempuh sehingga peranan dan fungsi komunitas lokal dapat merupakan bagian dari fungsi hukum sebagai social engineering dan fasilitator dapat meningkatkan kesadaran hukum dan HAM. Ketiga, alternatif apakah yang perlu dikedepankan sehingga komunitas lokal dapat menjadi mitra pemerintah terpadu dalam menginstitusionalisasikan kesadaran hukum dan HAM melalui produk hukum dan kebijakan daerah.

\section{Komunitas Lokal Dalam HAM Internasional}

Komunitas lokal yang dimaksudkan dalam tulisan inj tidak berdiri sendiri, melainkan lebih memperlihatkan keterkaitan antara konsep, nilai, norma, dan juga struktur sosial yang satu sama lain berfungsi dalam menjembatani lahirnya kesepakatankesepakatan untuk mencapai suatu tujuan yang diinginkan masyarakat. Tidak heran jika ada klaim bahwa prinsip-prinsip dasar HAM telah hadir sebelum Magna Charta di Inggris dan Amerika Serikat. Praktik kesetaraan telah dijadikan pedoman sahabat dan masyarakat Arab, ketika Nabi menjadi pemimpin umat.

Dalam keyakinan muslim, ajaran Islam bersifat universal dan kesenangan memiliki kesesuaiąn dengan jajaran HAM yang datang setelahnya terhadap komunitas lokal dan keanekaragamnya telah disebutkan dalam Al-Qur'an.

“Sesungguhnya Tuhan telah menciptakan manusia terdiri dari laki-laki dan perempuan, bersuku-suku,berbangsabangsa agar kamu saling mengenal. Sesungguhnya yang paling mulia diantara kamu disisi Allah adalah yang paling bertakwa". (Q.S. Al-Hujurat:13)

Adanya masyarakat yang pluralis telah mendapatkan pengakuan yang jelas, sehingga kerangka filosofis ini, jika dijadikan acuan teoritik tidak akan kontradiksi, bahkan justru saling menguatkan. Namun, realisasinya ayat tersebut menuntut adanya kesederajatan antara sesama manusia.

\section{Hak Penduduk Suku Asli (Indigineous People)}

Nilai-nilai dan norma-norma yang telah mendapatkan kesepakatan masa lalu, dalam kehidupan moderen masih menjadi sujukan dipandang sebagaj kearifan lokal (local wis 
dom). Konsekuensi dari komunitas lokal tersebut menimbulkan sekelompok masyarakat, yang dalam konteks sejarah penjajahan disebut kelompok masyarakat suku asli (native (indigeneous). Mereka termasuk suatu kelompok masyarakat yang secara sosial, ekonomi, budaya masih terbelakang dan karenanya mereka tidak memperoleh keuntungan dari hasil ilmu pengetahuan dan teknologi moderen.

Jadi dalam konteks ini, komunitas lokal tidak dibatasi hanya pada kesatuan masyarakat dalam ukuran geografis, melainkan juga nilai-nilai yang hidup dalam masyarakat setempat. Hal ini ditandai oleh adanya interaksi antara nilai-nilai global dengan nilai-nilai lokal. Bahkan ada nilai-nilai lokal yang sama sekali belum berubah, meskipun ada perubahan luarnya. Jadi, komunitas lokal esensinya terkait dengan kosa kata 'indigineous people' dalam bahasa Inggris. Namun, tidaklah secara serta merta komunitas lokal identik dengan masyarakat suku asli yang masih primitif.

Bilamana memperhatikan pada periodesasi perkembangan HAM, maka prinsip dasar mengenai hak-hak komunitas lokal termasuk pada perkembangan HAM dalam generasi terakhir. Suatu perkembangan HAM ditandai oleh adanya jaminan hak-hak bekerjasama, terutama dalam penanganan persoalan yang melibatkan banyak negara. Apakah dalam kaitannya dengan solidaritas atas bantuan malapetaka bencana alam atau bencana kemanusiaan seperti peperangan. Lebih khusus lagi, kehadiran pasal 28 Universal Declaration for Huma Rights 1948, mengandung kewajiban untuk mengembangkan hal-hak sosial, ekonomi, dan hak ikut serta dalam mengambil manfaat bagi warisan budaya umat manusia masa lalu. ${ }^{2}$

Beberapa pakar, seperti Henry J. Steiner dan Philip Alston, Dominic
McGoldrick, AH. Robertson dan J.G. Merrills, berpendapat bahwa persoalan the people rights, atau hak-hak atas penduduk asli telah mendapat pengakuan yang tegas dalam Konvensi Internasional tentang HakHak Sipil dan Politik sejak tahun 1966.

Dalam pasal 26 , dengan tegas dinyatakan;

"All persons are equal before the law and are entitled without any discrimination to the equal protection of the law. In this respect, the law shall prohibit any discrimination and guarantee to al person equal and effective protection against discrimination on any ground such as race, color, sex, language, religion, political, anotheropinion national or social origin, property, birth and other status.

Meletakkan manusia dalam situasi dan keadaan apapun wajib ditempatkan secara sederajat di depan hukum. Sehingga bentuk perlakuan diskriminatif, apakah karena suku, ras, agama, dan bahasa mutlak menjadi terlarang. Sebaliknya, terdapat suatu negara yang sebagian besar penduduknya memainkan peranan dominan, maka tidak dapat dipungkiri adanya kelompok minoritas yang perlu mendapatkan perlindungan. Dalam pasal 27 ICCPR ditegaskan sebagai berikut:

In those states in which ethnic, religious or linguistic minorities exist, person belonging to such minorities shall not denied the rights, in community with the other members of their groups, to enjoy their own culture, to profess and practice their own religion, or to use their own language.

2 Lihat penjelasan rinci, J. Thontowi. HAM dan Hukum 1 Internasional dan Prospeknya Dalam Kebinet Persatuan Nasional. Alam Jurnal Magister Hukum. Vol 2. 1. Februari. 2000: HI 27. 
Hak dasar minoritas karena suku, agama, dan bahasa memang harus diakui dalam masyarakat. Namun, perlindungan bagi mereka untuk menerapkan apa yang telah menjadi keyakinan perlu mendapatkan jaminan secara pasti dalam suatu hukum dasar. Bagaimana tarik ulur antara kelompok mayoritas dan minoritas dalam konteks HAM. Selagi kerangka pikir penerapan demokrasi bukan sekedar mayoritas absolut atau tirani minoritas, maka kesepakatan untuk memperjuangkan kepentingan publiktidak perlu dikhawatirkan. Asalkan esensi demokrasi, yaitu kekuatan mayoritas yang berkuasa menuntut jaminan perlindungan atas hak-hak minoritas, didukung oleh pengakuan hukum yang tegas dan pasti.

Terhadap pasal 27 tersebut Rosalyn Higgins lebih menegaskan bahwa argumen tentang kelompok minioritas tersebut harus dipandang sebagai orang atau people dalam kaitannya dengan Konvensi ICCPR dan karenanya mereka memiliki hak untuk selfdetermination. Istilah self-determinationtidak harus selalu diartikan sebagai memisahkan pemerintahan sendiri (self-governing), melainkan dapat juga degan memberikan hak-hak khusus atau daerah otonomi dan istimewa. Wujud self-determination tidak selalu dimaknai dengan membentuk pemerintah sendiri, melainkan lahirnya negara-negara bagian atau federasi. Sedangkan dalam sistem negara kesatuan, otonomi khusus atau keistimewaan merupakan bentuk lain dari self-determination.

Menurut Dominic, kedua pasal tersebut di atas sangat penting bagi suatu negara untuk menerapkannya dalam sistem hukum, konstitusi, undang-undangnya yang mengatur tentang kedudukan dan keberadaan suatu masyarakat, termasuk penduduk suku asli (indigeneos people).
Aplikasi dari kedua pasal terebut, telah dengan tegas dicantumkan dalam beberapa konstitusi, sepeti Canada terhadap suku Indian, Australia terhadap suku Aborigin, Inggris dan Amerika Serikat terhadap suku Indian. ${ }^{3}$ Suku Indian, Aborigin, dan Maori adalah masyarakat asli atau pribumi yang dalam pandangan penjajah terbelakang dan tergolong minoritas.

\section{Perlindungan Terhadap Suku Asli yang Minoritas}

Studi-studi yang terkait dengan HAM secara internasional dan memusatkan perhatiannya pada persoalan minoritas, telah mendorong PBB untuk mendirikan suatu Sub Komisi Perlindungan terhadap Diskrimikasi dan Perlindungan terhadap Minoritas (the sub - commission on prevention of discrimination and protection of minorities). Pada tahun 1981, sub komisi tersebut membentuk grup kerja (working group) tentang penduduk suku asli (indigineous population). Suatu komisi yang didirikan bulan Agustus 1982.

Tugas komisi antara lain merumuskan tentang hak-hak penduduk, suku asli dan mengidentifikasi hasil rumusan standar terkait dengan hak-hak mereka. Termasuk mencari alternatif untuk melindunginya dari ancaman kehancuran budaya mereka. Baru tahun 1994, rumusan tentang hak-hal dasar penduduk asli tersebut ditetapkan. Keberhasilan tersebut tidak lepas dari peran LSM dunia yang mewakili masyarakat asli

3 Pembahasan sangat kmprehensif terhadap indigineous people dan ICCPR dilakukan oleh Dominic McGoldrick. The $\mathrm{Hu}$ man Rights Committee: Its Role in the Development of the Intemational Covenant on Civil and Political Rights. Oxford Clarendon Press. 1994; hal 21. 
dunia, dan berada dalam sub komisi di PBB. ${ }^{4}$

Dalam pasal 1 dari Konvensi No. 169 tentang Indigenious and Tribal People in Independent Countries, yang diadopsi sejak tahun 1989. Indigineous People disebutkan bahwa terdiri dari ;

1). Konvensi menyebutkan tentang siapa sebenarnya indigeneous people yang antara lain ;

a. Masyarakat suku-suku (Tribal People) dalam negara yang merdeka yang secara sosial, budaya, dan kondisi ekonomi berbeda dari komunitas masyarakat nasional lainnya. Status mereka sebagian atau seluruhnya ditentukan oleh hukum adat, tradisi, atau hukum yang khusus.

b. Orang-orang di negara yang merdeka dianggap sebagai pribumi atau asli 'indigeneuos' yang dihubungkan dengan asalusul kependudukan, dimana mereka yang menempati suatu negeri atau tempat atau wilayah tertentu, milik suatu negara yang berada dibawah pengaturan hukum negara penjajah.

2). Identitas diri sebagai masyarakat asli dipandang sebagai kriteria fundamental untuk menentukan group mereka.

3). Orang atau 'people' dalam konvensi ini tidak dapat ditafsirkan kecuali mereka yang dalam hukum internasional di lindungi hak-hak dasarnya.

Siapa yang bertanggungjawab atas perkembangan dan pembangunan mental masyarakat lokal. Dalam pasal 2, baru ditegaskan bahwa ; negara berkewajiban untuk mengembangkan atau membangun mereka, 'Government shall have the responsibility for developing with the participation of the peoples concemed, coordinates and systematic action to promole the rights of these people and to guarantee respect for their integrity'.

Latar belakang lahirnya istilah indigenous people dalam konvensi ini terkait dengan kondisi suatu negara yang secara sosial, politik, budaya, dan ekonomi dijajah oleh negara-negara lain.

The history of indigenous peoples has universally included exploitation by other groups, often in the form of harsh colonization, and generally involving one or another degree of dispossession from hereditary lands and destruction of native culture. Such people - referred to in different cultures or states in different ways, including Indians, nation, aboriginals, natives, tribes or band have long been plagued by the sense of inferiority imposed upon them by the dominant culture. They have rarely participated in a serious way in govemance or decision - making in their states of residence on matters of vital significance for them. They have generally gained little from the economic development of those states. The centuries - long struggle in the Westem Hemisphere between such peoples and the states in which they live forms part of a well-known history". ${ }^{5}$

Realitas sejarah tersebut menunjukkan bahwa; kata indigenous people diakui sebagai suatu komunitas sosial yang ditandai oleh kondisi minoritas atau

4 Meskipun sejarah komisi khusus 'indigeneous people' tidak memerinci secara detil. Keterangannya dalam karya A.H. Robertson dan J.G. Meriill cukup komprehensif. Human Rights in The World An Introduction to the Study of the Intemational Protection of Human Rights. Menchester and New York University Press. 1996 ; 91-93.

${ }^{5}$ Op. Cit. hal. 
mayoritas, tetapi secara politik tidak memiliki kontribusi dalam penentuan nasibnya sendiri. Mereka juga menderita karena tersingkirkan oleh kekuatan Iuar untuk dapat menggunakan warisan mereka, termasuk hancurnya budaya pribumi. Contohnya, suku Indian diAS, suku Aborigin di Australia. Mereka juga jarang terlibat dan ambil bagian dalam mekanisme pemerintahan, karena mereka memang merasa tidak memiliki pendidikan yang cukup. ${ }^{6}$

Jelas bahwa makna komunitas lokal tidak identik dengan masyarakat asli yang terbelakang, sebagaimana ditegaskan dalam konvensi. Namun, relevansi konvensi tersebut masih tetap dapat dipergunakan. Mengingat di berbagai negara seperti Suku Dayak di Kalimantan, Kubu di Sumatera Selatan, Baduy di Jawa Barat adalah sekelompok masyarakat yang dapat dikelompokkan pada suku asli (indigeneous people).

Identitas masyarakat atau komunitas lokal yang telah jelas parameternya, akan menjadi kabur status dan perlindungannya, bilamana tidak ditegaskan tentang siapa yang bertanggungjawab melindungi dan mengembangkannya. Bilamana pertanggungjawaban inj dibebankan pada negara, maka itu berarti rakyat memiliki hak untuk memberikan respon jika pemerintah gagal memenuhi kewajibannya.

Dengan demikian, kedudukan hukum dan hak-hak dasar dari masyarakat suku asli, termasuk institusi sosialnya atau pranata sosialnya semula telah menjadi obyek dari kekuasaan penjajahan. Seiring dengan munculnya negara-negara merdeka, maka hak-hak penduduk asli yang minoritas termasuk pranata sosialnya wajib dilindungi dan dihormati oleh negara. Dalam praktiknya, perlindungan terhadap hak-hak masyarakat asli tersebut secara implisit memang terdapat dalam Konvensi DUHAM 1948, dan secara lebih tegas dilindungi oleh ICCPR 1966 dan dikonkretkan dalam Konvensi PBB tahun 1992 tentang Hak-hak dasar masyarakat suku asli.

\section{HAM Dalam Sistem Hukum Nasional}

Dalam sistem hukum Indonesia, istilah komunitas lokal memang tidak populer dan ditemukan dalam kalimat yang berbedabeda. Makna yang terkandung di dalamnya lebih pada dimensi sosiologis. Sehingga dalam literatur hukum, istilah-istilah yang dipergunakan untuk komunitas lokal berbeda-beda. Ada yang menyebut kesatuan hukum dan masyarakat adat. Ada juga yang menyebutkan masyarakat tradisional. Baik istilah kesatuan hukum adat maupun masyarakat tradisional adalah istilah yang ada dalam komunitas lokal Indonesia. Akan tetapi juga telah dilengkapi dengan hadimya nilai-nilai modernitas yang tak terpisahkan dengan sistem sosial seutuhnya.

Seberapa jauh komitmen pemerintah R] terhadap perlindungan hak-hak dasar masyarakat suku asli (indigeneous people). Pada masa orde baru, perjuangan untuk mempromosikan dan meningkatkan nilainilai fundamental HAM secara umum sangat kurang. Keadaan ini bukan saja dibuktikan melalui sedikitnya upaya pemerintah melaluj ratifikasi konvensi internasional tentang HAM, juga pelanggaran HAM berat bagitu banyak jumlahnya. Sejak tahun 1992-an, arah perkembangan HAM tampak mulai

6ajian yang luar biasa tentang HAM internasional, khususnya 'indigenous people', bias dilihat Henry J. Steiner dan Philip Alston. International Human Rights in Context. Oxford, New York. Clarendom University Press. 1996. Hal, 106, 1011. 
berkembang positip. Langkah positip reformasi 1998, terutama dipicu dengan terjadinya amandemen terhadap UUD 1945. Perlindungan HAM terhadap masyarakat terbukti semakin kuat.

\section{Komunitas Lokal dalam UUD 1945}

Bila dibandingkan dengan situasi sebelumnya, UUD 1945 hasil amandemen jauh lebih memiliki kepastian hukum dalam memberikan perlindungan terhadap dasar masyarakat. Sebelumnya, UUD 1945 hanya memuat sekitar hak-hak dasar (yaitu pasal $27,28,29,31,33$, dan 34). Instrumen hukum melalui konstitusi ini terbukti tidak memadai bagi upaya menjadikan pasal-pasal tersebut, upaya agar hukum berfungsi efektif dalam mereka yang kondisi sosial dan tekhnologi masyarakat (Law is as a tool of social and political engineering). Lebih dari itu, pendekatan yang saat ini perlu dikembangkan adalah pendekatan hukum lebih progresif, responsif, dan fasilitatif. ${ }^{7}$ Ketentuan hukum sebagai pengatur, penentu, pengarah, dan pencegah timbulnya penyalahgunaan kewenangan hanya mungkin tercipta bilamana rakyat ikut ambil bagian dalam proses pembuatan putusan dan kebijakan serta peran pengawasan terhadap pemerintah.

Karena itu, desakan global dan lokal telah menuntut UUD 1945 memuat nilai-nilaj dasar bagi warga negara lebih rinci. Tuntutan tersebut terbukti direspon positif oleh kebanyakan masyarakat. Artikulasi kekuatan suara masyarakat ini tercermin dalam sikap dan pendapat anggota-anggota MPR, khususnya PAHIV yang bekerja sejak tahun 1999 s/d 2002 untuk mengamandemen UUD 1945. Perubahan HAM dalam UUD 1945 hasil amandemen terbukti dengan melahirkan bab tersendiri. Pasal 27 dan 28 dan Bab XA tentang Hak Asasi Manusia yang isinya menjadi 10 pasal dan 26 (ayat). Kelengkapan dan tersedianya pasal-pasal mengenai HAM begitu rinci dapat berfungsi selain perlindungan atas hak rakyat semakin jelas. Juga rakyat memiliki kepastian dalam mencegah terjadinya penyalahgunaan kekuasaan.

\section{Komunitas Lokal vs Masyarakat Hukum Adat dalam UUD 1945}

Meskipun hubungan langsung antara komunitas lokal dengan kata indigeneous people dalam konvensi internasional memang tidak tampak, mengisyaratkan adanya korelasi muatan materi UUD 1945. Misalnya, komitmen pemerintah RI terhadap HAM Internasional, khususnya terkait dalam persoalan "indigeneous people" tercermin dalam beberapa pasal dalam UUD 1945 dan Aturan Undang-Undang lainnya. Pasal 28 c (ayat2) ; Setiap orang berhak untuk memajukari dirinya dalam memperjuangkan haknya secara kolektif untuk membangun masyarakat, bangsa, dan negaranya. Secara Jebih khusus, pasal 28 I ayat (2) ; Setiap orang berhak bebas dari perlakuan yang bersifat diskriminatif atas dasar apapun dan berhak mendapatkan perlindungan terhadap perlakuan yang bersifat diskriminatif. Dalam ayat (3) ; Identitas budaya dan hak masya-

${ }^{7}$ Fungsi hukum yang responsif diartikan bukan sekedar hukum yang adaptif, terbuka untuk menunjukkan suatu kapasitas beradaptasi dan bertanggungjawab, melainkan suatu institusi yang responsif mempertahankan halhal yang kuat yang esensial bagi integritasnya. Sembari tetap memperhatikan atau memperhitungkan keberadaan kekuatan-kekuatan baru di dalam lingkungannya. Phillippe Nonet \& Phillip Selznick. Hukum Responsif : Pilihan dan Masa Transisi. Jakarta. FF: HUMA. 2003. Hal. 59. 
rakat tradisional dihormati selaras dengan perkembangan zaman dan peradaban.

Konsep masyarakat tradisional merupakan satu indikator penting atas kedudukan substantif komunitas lokal. Sehingga menjadi relevan bilamana komunitas loka! ini dihubungkan dengan sifat-sifat masyarakat hukum adat. Soepomo, Ter Haar, Van Vollenhoven setuju untuk menetapkan empat ciri masyarakat hukum adat. Keempat ciri tersebut yaitu ; terkait dengan aspek magis dan keagamaan (magic religious), tradisi dan kebiasaan (common), dalam transaksi obyeknya konkret (concrete), dan sifatnya elastis (flexible). Hilman Hadikusumah menambahkan empat yaitu, terbuka-sederhana, tidak dikodifikasi, kebersamaan atau gotong royong, dan musyawarah atau mufakat. ${ }^{8}$

Kelemahan yang secara implisit adalah kesan kuat setengah hati negara untuk memberikan perlindungan terhadap komunitas lokal. Namun, tidaklah juga tepat asumsi tersebut. Sebab, upaya ini lebih pada proses yang gradual yang bilamana tidak disediakan aturannya, maka kondisi mereka akan jauh lebih berbahaya.

Untuk memajukan penegakan HAM tersebut tidak lepas dari peran negara, sehingga dalam pasal 28 I ayat (4) dan (5). Isinya antara lain sebagai berikut ; ayat (4) Perlindungan, pemajuan, penegakan dan pemenuhan hak asasi manusia adalah tanggungjawab negara, terutama pemerintah. Ayat (5) ; Untuk menegaskan dan melindungi hak asasi manusia sesuai dengan prinsip negara hukum yang demokratis, maka pelaksanaan hak asasi manusia dijamin, diatur, dan dituangkan dalam peraturan perundang-undangan. Ketentuan ini berartiselaras dengan tuntutan dari pasal 2 Konvensi Intemasional No. 169 Tahun 1989.

\section{Komunitas Lokal dalam UU Otonomi Daerah}

Secara lebih khusus perlindungan komunitas loka! juga diatur dalam UU No. 32 tahun 2004 tentang otonomi daerah. Dalam pasal 2 ayat (8) negara mengakui dan menghormati satuan-satuan pemerintahan daerah yang bersifat khusus atau bersifat istimewa yang diatur dengan Undang-Undang. Sedangkan kesatuan masyarakat hukum adat, ditegaskan dalam pasal 2 ayat (9); Negara mengakui dan menghormati kesatuan-kesatuan masyarakat hukum adat beserta hak tradisi. alamnya sepanjang masih hidup dan sesuaj dengan perkembangan masyarakat dan prinsip negara kesatuan Republik Indonesia".

Apakah istilah kesatuan hukum adat dalam konteks ini sama dengan masyarakat tradisional sebagaimana disebutkan dalam pasal 28 I ayat (3). Dengan demikian, tidaklah naif jika komunitas lokal juga dapat mengambil sampelnya dengan DIY, Aceh, dan Papua. Meskipun ketiga daerah tersebut dipandang sebagai komunitas lokal, kekuasaan dan keistimewaan mencerminkan nilai-nilai yang berbeda dengan tuntutan modernitas.

Pasal ini dilengkapi dengan lahimya UU No. 18/2001 tentang Undang-Undang Otonomi Daerah Kekhususan Nanggroe Aceh Darussalam. Juga Undang-Undang tentang Otonomi Khusus Papua. Dan sedang menyusul, lahirnya UU tentang

secara mendalam Moch. Koesnoee menjelaskan hal itu dalam Hukum Adat Dewasa Ini. Yogyakarta. Pusat Penelitian dan Pengabdian Masyarakat. FH UII 1983. Hal 15. juga lihat Hilman Hadikusumah. Pengantar Ilmu Hukum Adat Indonesia. Bandung. Mandar Maju. 1992. Hal. 32-38. 
Propinsi Daerah Istimewa Yogyakarta. Ketiga Undang-Undang tersebut, memperkuat legitimasi substansi hukum masyarakat lokal beserta pranata sosialnya. Sebagai contoh, lahimya UU No. 18 Tahun 2001 tentang Pelaksanaan Otonomi Khusus Nanggroe Aceh. Letak persoalannya, seberapa jauh Pemerintah Daerah dan DPRD NAD mampu mengartikulasikan tuntutan masyarakat tentang ajaran syariat Islam.

\section{Larangan Diskriminasi Terhadap Minoritas (UU No. 39/ 1999)}

Masalah diskriminasi dan minoritas, perlindungan komunitas lokal dalam UU No. 39 tahun 1999 tentang Hak Asasi Manusia tertera dalam beberapa pasal sebagai berikut ;

Pasal 26 ayat (1) ; Dalam rangka penegakan hak asasi manusia, perbedaan dan kebutuhan dalam masyarakat hukum adat, harus diperhatikan dan dilindungi oleh hukum, masyarakat, dan pemerintah. Ayat (2) ; Identitas budaya masyarakat hukum adat, termasukhak atas tanah wilayah dilindungi selaras dengan perkembangam zaman.

Sikap dan perilaku negara yang non diskriminatif itu berarti upaya untuk mewujudkan tercapainya tujuan hukum yaitu keadilan. Perolehan keadilan bukan sekedar adanya suatu putusan peradilan yang adil, melainkan juga model perlakuan yang adil dari aparat pemerintah terhadap masyarakat. Misalnya, bagaimana negara mampu mencegah kekuatan investor untuk mengambil alih tanah-tanah masyarakat lokal. Sebagaimana hak-hak masyarakat dayak, yang mempercayai tanah-tanah mereka keramat. Namun, dengan mudah diambil alih (tentu ada konsekuensi) oleh karena kekuatan investor, termasuk penebangan kayu di hutan.

Implikasi Otonomi Daerah yang dibarengi dengan adanya Pemilihan Kepala Daerah di beberapa tempat telah melahirkan sentimen kedaerahan. Situasi ini menjadi penghambat, oleh karena proses demokrasi yang menuntut penghormatan terhadap HAM, malah justru memicu diskriminasi. Model konflik yang menyulut dua kelompok masyarakat, seperti Madura dengan Dayak, berakibat suku Madura telah menjadi korban diskriminasi tersebut. Orang-orang dari suku Jawa, baik yang ada di Irian dan juga di Aceh dipandang penjajah. Kecenderungan nonputra daerah tidak mendapatkan posisi di pemerintahan telah dengan jelas tampak. Situasi memang lambat laun dapat kelam, jika mekanisme penyelesaian sengketa melalui prosedur hukum dapat dicegah secara pasti.

\section{Relativitas Implementasi HAM di Indonesia}

Persoalan komitmen pemerintah Indonesia terhadap konvensi internasional tersebut, dalam batas tertentu belum seiring dengan tuntutan internasional. Tentu saja pernyataan HAM universal 1948 dan konvensi lainnya dalam tataran konsep telah terjadi pertentangan. Barat dan Timur tetap sepakat dalam memformulasikan HAM universal. Namun, dalam realitas implementasi sangat relatif. Realitivitas tersebut umumnya dipengaruhi oleh nilai-nilai dan pandangan hidup yang berbeda.

Pandangan tersebut di atas diperkuat oleh kajian yang dilakukan oleh Chandra Muzaffor, dalam karyanya tentang HAM dalam wacana Barat dan Tradisi Timur.

Setidak-tidaknya ada dua alasan mengapa jurang antara implementasi HAM dalam pandangan Barat dengan masyarakat 
Timur, khususnya Indonesia masih berlang-sung. Pertama, konsep dasar HAM yang bermula dari nilai-nilai individual dan kebebasan sungguh merupakan wujud budaya Barat (Western View on Human Rights). Nilai ideologis yang menempatkan manusia sebagai pusat dan tujuan dari kerangka berpikir (Anthropocentris). Kekuatan akal atau rasio hukum dan biroksasi, kebebasan dan individu merupakan parameter utama dalam membangun dan mengembangkan budaya masyarakat.

Sementara di budaya Timur, manusia tidak menjadi pusat, sebab kolektivitas dan pemikiran teologis sangat mempengaruhinya. Relevan untuk dikemukakan pendapat Satjipto Rahardjo. Perkembangan yang terjebak ke dalam suasana konftik yang bias memuncak pada pelanggaran HAM sendiri, terutama sejak HAM sudah memasuki generasi ketiga, yang antara lain memuat hak atas warisan budaya. Ini tentunya mengandung pengakuan dan penghomatan terhadap tradisi, kosmologi dan lain-lain yang mengandung nilai bagi komunitas bersangkutan. ${ }^{9}$

Bilamana disederhanakan tantangan konkret dari implementasi HAM dunia terkait dengan dasar negara Indonesia. Pancasila sebagai dasar ideologi negara mengisya- ratkan bahwa negara dan agama tidak terpisahkan. Adanya keseimbangan peluang dan tantangan tentang implementasi HAM dunia menghasilkan pelaksanaan

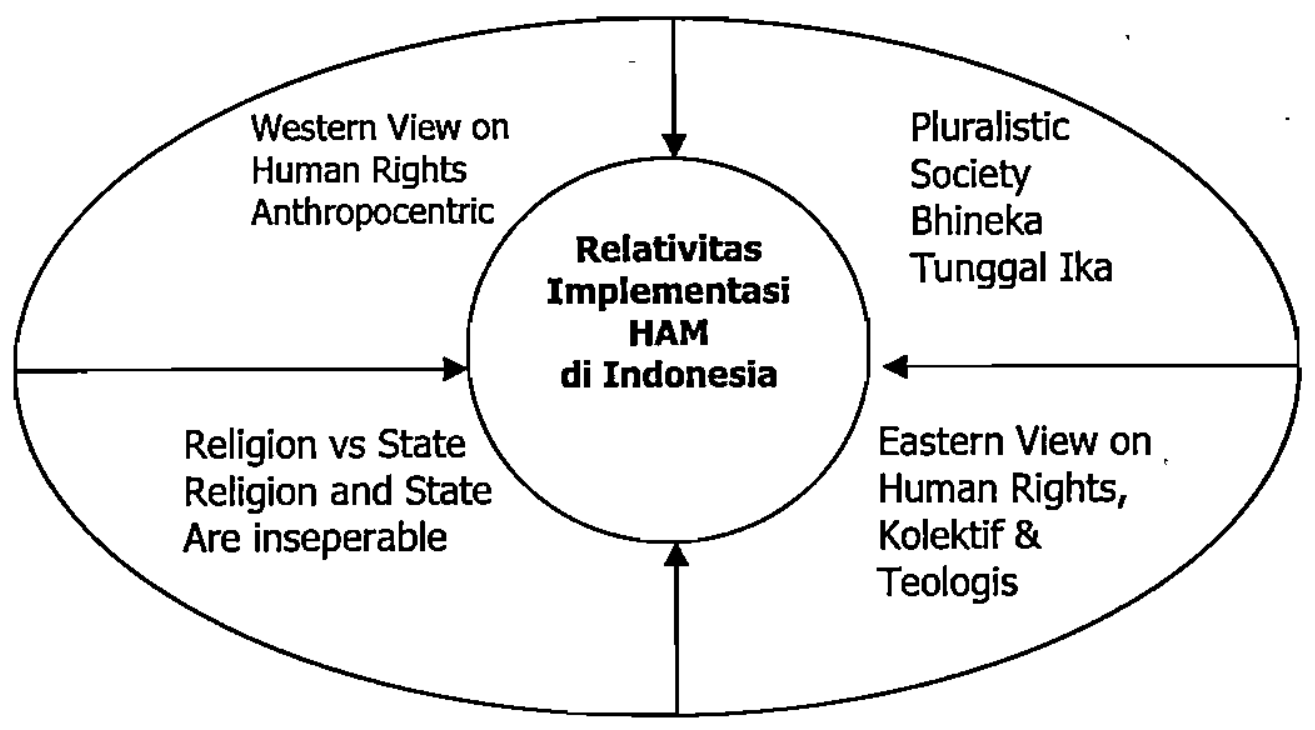

Gambar 2

Relatifitas Implementasi HAM di Indonesia

sehat dari usaha pemajuan HAM adalah melalui 'pengakuan terhadap kemajemukan' di dunia ini (Bhinneka Tunggal Ika). Tanpa mengakui kemajemukan tersebut, maka alih-alih memajukan HAM dunia malah akan
HAM di Indonesia yang relatif. Di luar aspek tersebut, relativitas implementasi HAM

${ }^{9}$ Satjipto Rahardjo. Hak Asasi Manusia Dalam Masyarakatnya. PT.Rafika Aditama. 
dalam kaitannya dengan hak-hak dasar komunitas lokal adalah keberadaan undangundang sektoral yang tumpang tindih yang begitu dominan dalam membatasi terwujudnya perolehan hak-hak komunitas lokal, termasuk hak-hak atas tanah mereka.

UU No. 5 Tahun 1950 tentang Pokokpokok Agraria dan sistem pembagian dan pemilikan tanah yang terlalu sentralistik. Hak milik berfungsi sosial (pasal 3) dalam realitas menempati masyarakat lebih lemah dan acapkali harus menerima jika yang memohon pemerintah atau pejabat pemerintah. Belum lagi UU Kehutanan dan UU Investasi Asing turut menghambat realisasi hak-hak masyarakat lokal. Sama halnya dengan penetapan atas hutan lindung dan hutan cagar budaya juga dapat menempatkan pihak masyarakat untuk mengalih atas kepentingan umum. Investasi sebagai pemilik modal sering dimanangkan bila yang dihadapi rakyat kecil dan mereka yang punya uang dan kekuasaan.

Dalam analisanya, Marco Kusumawidjaya menyimpulkan bahwa, fenomena penggusuran sesungguhnya telah memperlihatkan total kesenjangan dengan perhatian atas penanganan negara terhadap pemanfaatan atau tanah perencanaan spasial dan distribusi sumber daya lain. ${ }^{10}$

Dengan demikian, posisi komunitas lokal dalam sistem hukum Indonesia tidak saja terlindungi secara juridis, melainkan dalam penerapannya dapat disesuaikan dengan perkembangan dan kemampuan masyarakatnya.

\section{Signifikansi Hukum Terhadap Fungsi Komunitas Lokal.}

Bilamana budaya dan komunitas lokal telah diakui dan dilindungi, baik dalam ketentuan HAM intemasional maupun dalam sistem hukum nasional, maka aspek-aspek komunitas lokal dapat dipergunakan sebagai institusi yang memainkan peranan dalam merubah dan meningkatkan kesadaran hukum dan HAM masyarakat.

Secara jujur, institusi sosial yang saat in berperan dalam menciptakan masyarakat lebih banyak dipengaruhi oleh struktur formal pemerintah dan penegak hukum. Tidaklah berlebihan jika komunitas lokal kurang berperan. Birokrasi pemerintah yang rasional untuk urusan dan kepentingan publik dilakukan secara keseluruhan oleh struktur formal. Begitu pula, aturan-aturan main yang menjadi sumber petunjuk dan prilaku negara dan pemerintah sangat tergantung pada hukum positif. Konsekuensinya, akar-akar budaya dan institusinya tidak mendapatkan ternpat yang layak. Kalau toh nilai-nilai dan norma-norma hukum termasuk institusinya beroperasi, maka itu terbatas pada aspek-aspek privat. Hukum keluarga, perkawinan, warisan, dan upacara ritual keagamaan. Sedangkan aspek-aspek hukum publik sangat dipengaruhi oleh dimensi negara dan pemerintah.

Perkembangan tata pemerintahan dan iklim demokrasi yang tumbuh dalam situasi masa lalu masih bersifat asymetris (ada hasil yang positif dan juga ada yang negatif). Pilihan-pilihan yang ditawarkan ketika itu sangat terbatas. Dewasa ini, pilihan-pilihan bagi masyarakat cenderung semakin terbuka. Salah satunya yaitu adanya signi-

2005. Pandangan tersebut di atas diperkuat oleh kajian yang dilakukan oleh Chandra Muzaffor, dalam karyanya tentang HAM dalam wacana Barat dan Tradisi Timur.

10 Lihat Marco Kusumawidjaya. Penggusuran Suatu Penanganan Primitif Terhadap Permasalahan Moderen. Dalam Jumal Demokrasi. Forum LSM DIY. Vol. II. 1 Januari 2004. Hal. 73-76. 
fikansi hukum terhadap upaya-upaya menghormati dan mengangkat kearifan lokal (local wisdom) dan komunitas lokal (local community). Istilah ini lebih dekat untuk ditegaskan sebagai bagian dari kebiasaan atau hukum kebiasaan (customary rules). Namun, dalam proses perkembangannya diperlukan peran aktif Pemerintah Daerah / Kota, DPRD baik di tingkat Propinsi maupun Pemerintah Kabupaten dan Kota. Keberadaan peran dan fungsi dari institusi pemerintah dalam mengartikulasikan kepentingan masyarakat tidaklah diragukan. Kepentingan Publik, privat, dan sosial (domein state, formal, dan domein non-state, yang berawal dari ketidaksamaan pemahaman perlu diluruskan melalui suatu kesepakatan. Dalam proses pembuatan PERDA agar pertikaian tidak berkepanjangan, mereka yang ada dalam pertikaian pendapat harus berakhir dalam suatu akumulasi. Titik akumulasi tersebut ditentukan oleh seberapa jauh akomodasi kelompok kepentingan ke dalam Perda."

\section{Ninik Mamak dan Kades sebagai Komunitas Lokal}

Dalam perspektif epistemologis, kearifan lokal mengandung dimensi abstrak,

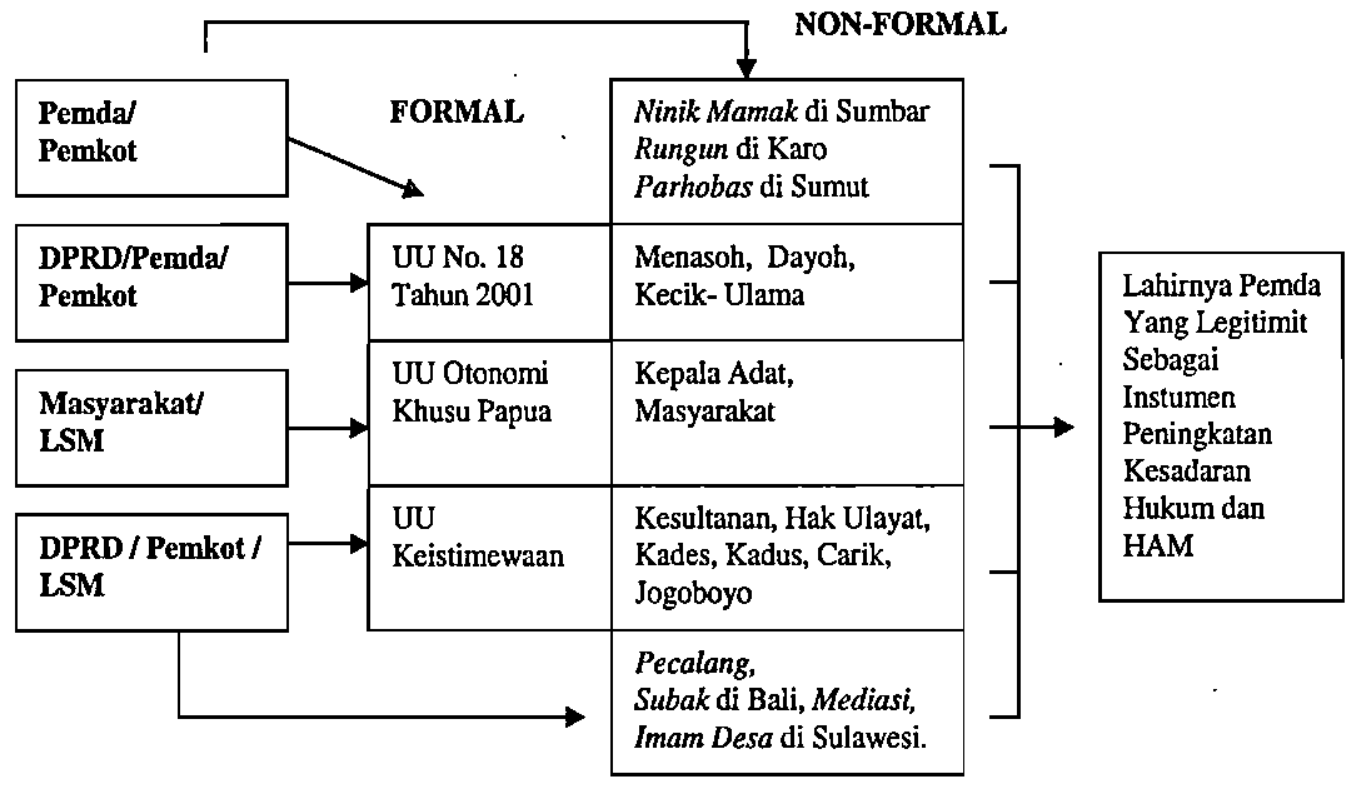

\section{Gambar 3}

Hubungan antara Peran Pemerintah, DPRD, Masyarakat dengan Kepentingan Lokal melalui Kebijakan Legislasi atau Perda.

non formal) menjadi perlu diperjuang-kan melalui kebijakan hukum dan politik dengan wujud munculnya Peraturan Daerah.

Karena proses pembuatan PERDA tidak selalu mulus, maka perbedaan persepsi seperti nilai-nilai norma-norma tradisi, kebjasaan, dan juga budaya suatu masya-

" Lihat Fauzi Ismail, dkk. Libatkan Rakyat Dalam Pengambilan Kebijakan. Yogyakarta. Forum L.SM DIY. 2005. Hal. 61. 
rakat, termasuk seni dan bahasa. ${ }^{12}$ Sedangkan ketertiban atau institusi adat sebagaimana ditemukan di berbagai tempat dalam masyarakat Indonesia lebih memainkan peranannya pada segi-segi hukum perdata. Misalnya, lembaga adat 'ninik mamak' di Sumatera Barat, masih berfungsi efektif dalam kedudukannya sebagai penata harta kekayaan, khususnya tentang data-data tanah, luasnya, batasnya, dan juga penyelesaian damai jika terdapat sengketa. Menariknya, dalam sistem ini wanita memiliki peran dominan dalam penguasaan harta kekayaan khususnya sistem pewarisan tanah keluarga.

Bahkan dalam konteks status hak tanah dan tanah bagi seseorang menjadi sangat efektif ketika mereka menjadi suatu kewajiban untuk membayar pajak sebagai salah satu sumber PAD. ${ }^{13} \mathrm{Di}$ luar urusan perdata, khususnya kedudukan kepala desa (Kades) memiliki legitimasi hukum yang sangat kuat. Di satu pihak, kedudukan dan tugas Kades diatur dalam UU. No. 5 Tahun 1979 dan juncto UU No. 22 Tahun 1999, yang tugas dan kewajiban Kades.

Namun, sejak sebelum ada peraturan tersebut, tugas kades begitu luas. Kekuasaan legislatif, eksekutif, dan judikatif seakan-akan berada di satu tangan. Menurut Nur Hasan, kekuasaan Kades yang begitu rupa telah diakui sejak negara kita belum merdeka, yang menempatkan Kades sebagai Bapak Masyarakat Desa. Konsekuensi lebih lanjut, Kades dianggap mengetahui segala peraturan-peraturan adat dan hukum adat masyarakat adat yang dipimpinnya. Oleh karena itu, Kades adalah juga Kepala Adat. ${ }^{14}$

Seiring dengan itu, status 'nagari' di Sumatera Barat, telah mengalami perubahan yang begitu fundamental. Tidak saja dipandang sebagai institusi adat yang merepre- sentasikan kelembagaan adat dan Islam. Lebih dari itu, saat ini 'nagari' dipandang sebagai mitra pemerintah yang memiliki fungsi struktural formal. Hal ini juga dikukuhkan melalui putusan DPRD, dalam PERDAnya. Akibatnya, sistem pemerintahan desa Minangkabau sepertinya berada dalam duality system. Sistem nagari yang semula berdiri mengatasnamakan kekuasaan adat, yang saat ini juga dapat mewakili pemerintahan desa. Lembaga adat yang juga terkait dengan urusan-urusan perdata, tetapi juga terkait dengan persoalan publik dan keamanan ditemukan di beberapa tempat. Hak Sultan atas tanah Sultan Ground dan rakyat mestinya diperhitungkan di Yogyakarta sebagai karakter dari komunitas lokal.

\section{Rungun di Karo dan Mediasi Imam Desa di Sulawesi Selatan}

Dalam konteks kekuasaan peradilan ' $j u$ dicial power' di beberapa tempat juga memiliki kekuasaan, seperti terlihat dalam kasus 'Rungun' dan 'Medias Imam Desa'. 'Rungun' adalah forum pertemuan yang dihadiri oleh tokoh-tokoh masyarakat di Batak Karo. Forùm ini biasanya dipergunakan dalam menyelesaikan pertikaian yang terkait dengan anggota masyarakat di suku, baik dalam persoalan pertikaian tanah dan

${ }^{12}$ Lihat Culture, Society, and the individual ,dalam Roger M. Keesing. Culture Anthropology. Canbera Halt Rinehart and Wisnston, Inc. 1981. Hal. 65.

${ }^{13}$ Lihat lebih lanjut tulisan Mudjiono. Eksistensi Hak Ulayat Dalam Pembangunan Daerah. Jurnal Hukum No. 26 Vol. Jl 2004. Hal. 152-165.

14 Lihat Nur Hasan Islamil. Otonomi Bidang Pertanahan : Reposisi Peranan Pusat dan Daerah dan Idiologi Politik Pertanahan. Mimbar Hukum No. 34/II/2000. Hal. 55. 
hal-hal lain dalam keluarga. Sifat putusan mereka mengikat, sehingga sekali sengketa telah disepakati, sangat sukar mereka melanggarnya.

Kontribusi 'rungun'dalam mengendalikan ketertiban masyarakat desa cukup efektif. Sebab, kepala-kepala adat yang membuat putusan sungguh dipatuhi pihakpihak yang bertikai. Kredibilitas 'rungun' diakui masyarakat Karo, karena kepala adat umumnya datang dari orang-orang terpandang, baik secara keturunan (hereditary). keagamaan (religiousity), dan juga status sosial. $^{15}$

Berbeda dengan mediasi Imam Desa di Sulawesi Selatan, yang terlibat dalam upaya pencegahan pembunuhan atas pelaku kawin lari (silariang). Kawin lari yang dilakukan oleh anak laki dengan perempuan dipandang oleh adat Bugis - Makassar sebagai pelanggaran berat hukum adat. Pihak keluarga perempuan yang dipermalukan memiliki hak untuk mengembalikan harga dirinya, melalui upaya yang melakukan pembunuhan hanya terhadap pelaku 'kawin lari' (laki-laki dan perempuan).

Kedua pelaku kawin lari tersebut, akan mudah dibunuh bilamana mereka tidak memohon perlindungan pada Imam desa. Selagi kedua pelaku kawin lari tersebut mengikuti prosedur hukum adat (seperti lari ke imam, menyerahkan urusan pernikahan dan damai), maka putusan imam tersebut memiliki daya ikat yang kuat. Sebab, dilarang hukumnya bagi keluarga perempuan yang dipermalukan untuk melakukan penyerangan ketika mereka berada di bawah perlindungan imam desa (traditional sanctuary refuge). Daya ikat dan sifat memaksa ini hanya ada dan terjadi di dalam masyarakat Sulawesi Selatan, khususnya suku Bugis dan Makassar.
Keputusan itu mendapatkan pengakuan dari masyarakat Bugis dan Makassar disebabkan seorang imam, selain memperoleh SK Bupati sebagai perangkat petugas keagamaan, juga dari kantor Departemen Agama. la juga dipandang sebagai kepala adat yang memiliki kompetensi dalam bidang pengetahuan agama dan praktek upacara keagamaan. Satu hal yang sangat berbeda bagi peran Imam Desa di Bugis dan Makassar yaitu dapat menyelesaikan sengketa keluarga, khususnya kawin lari 'silariang.' ${ }^{16}$ Seperti upacara perkawinan dan praktik damai (abodj).

Adapun kasus-kasus kawin lari yang tidak tertangani Imam Desa umumnya timbul dalam perkara pidana. Sebab, keluarga pihak perempuan umumnya mampu mengendalikan harga diri keluarga (appaenteng siri'na) dengan melakukan pembunuhan terhadap pelaku kejahatan pembunuhan tetap menjadi jurisdiksi penegak hukum negara, termasuk polisi, jaksa, dan pengadilan.

\section{Institusi Keamanan Desa}

Institusi lokal yang tidak kalah pentingnya adalah terkait dengan petugas keamanan desa. Dalam beberapa leteratur, seperti sejarah Banten yang ditulis Prof. Sartono, juga Anton Lucas, tentang peran 'Joara-Joara' di Banten, Jawa Barat turut

15 Penelitian mendalam telah dilakukan oleh Herman Slaat, pengajar Law School Neigmegen University Netherlands. Karyanya tersebut telah diterbitkan menjadi bukum yang diterbitkan di GAMA PRESS.

${ }^{15}$ Penelitian komprehensif telah dilakukan penulis, sekitar tahun 1992. Dan materi tersebut telah menjadi bagian dari Desertasi, Law and Custom in Makassar Society. The Interaction of Local Custom and National Legal System in Dispate Resolution. Ph.D Thesis, The University of Western Australia. 1997. 
serta menentukan barometer tatanan sosial dan tertib desa. Sejenis dengan itu, 'Pecalang' di Bali, 'Parhobas' di Sumatera Utara, 'Tobarani' di Sulawesi Selatan. Mereka ini secara institusional diakui sebagai lembaga adat yang memiliki fungsi dalam memelihara keamanan dan ketertiban desa secara tradisional. Kompetensi mereka ditandai oleh adanya kemampuan magis atau spiritual, kemampuan pisik dalam artian ketrampilan bela diri. Sehingga mereka juga dapat digolongkan menjadi masyarakat yang kharismatik.

Namun, karena mereka tidak memperoleh pengakuan dari sistem hukum moderen, peran dan fungsinya cenderung menjadi kurang positip. Pecalang di Bali dan Parhobas di Sumatera Utara sejak spirit otonomi Saerah muncul adanya revitalisasi. Di Bali peran pecalang terbukti cukup ampuh ketika persoalan bom Bali 22 November 2002. Termasuk peran mereka cukup disegani dalam upacara-upacara adat, termasuk dalam Kongres PDIP dan Kongres Partai Golkar. Setidak tidaknya peran mereka telah membantu proses pengamanan yang dilakukan oleh Polisi dan TNI. Sama halnya, Kapolda Sumatera Utara tahun 2003, telah mengakui pentingnya 'Parhobas' dala upaya menciptakan iklim yang aman dan tertib bagi masyarakat. ${ }^{17}$

Dari uraian di atas, jelaslah bahwa komunitas lokal baik bersifat keperdataan, kekeluargaan, maupun terkait dengan urusan publik seperti imam esa di Makassar, Pecalang dan Porhobas adalah fenomena konkret yang masih hidup dan memungkinkan untuk dipergunakan dalam upaya meningkatkan kesadaran hukum dan HAM masyarakat.

\section{Penutup}

Meskipun istilah komunitas lokal tidak ditemukan dalam konvensi internasional, sistem hukum Indonesia telah memberikan jaminan terhadap nilai-nilai lokal secara jelas dan pasti. Oleh karena itu, Reposisi Komunitas Lokal tidak saja penting dalam upaya meningkatkan kesadaran hukum dan HAM dalam masyarakat, melainkan merupakan kebutuhan yang harus selalu diperjuangkan. Secara juridis, konsep 'indigineous people' dalam Konvensi Internasional dapat diterapkan terhadap suku-suku asli Indonesia seperti suku Baduy, Kubu, Tengger, Dayak, dan suku Asmat di Irian. Namun, mereka ini tidak mewakili sepenuhnya konsep komunitas lokal.

Bilamana beberapa nilai tradisional dalam komunitas lokal masih dipraktikkan, nilai-nilai modernitas juga telah diadopsi lebih dominan. Oleh karena itu, kebutuhan untuk menata ulang peran dan fungsi kearifan dan komunitas lokal ke dalam satu sistem yang sinergis dengan peran pemerintah dewasa ini telah merupakan keniscayaan. Globalisasi yang ditandai oleh adanya kesadaran negara dan pemerintah Indonesia untuk merativikasi JCCPR 1966, dan konvensi HAM internasional lain seperti racial discrimination dan indigineous people merupakan bukti komitmen Indonesia terhadap masyarakat internasional. Seberapa jauh institusi-institusi sosial yang hidup menjadi living law dalam setiap masyarakat seiring dengan ketentuan hukum internasional dapat terakomodasikan ke dalam sistem hukum nasional dan juga pemerintah lokal.

Perlindungan dan penghormatan terhadap kearifan dan komunitas lokal telah diakui oleh UUD 1945, UU No. 39/1997, dan

${ }_{17}$ Informasi ini diperoleh ketika penulis sebagai anggota Komisi Konstitusi, berdiskusi dengan Kapolda bersama stafnya di Medan, Sumatera Utara, sekitar bulan Februari 2003. 
Komunitas Lokal dalam Perspektif HAM dan Hukum Nasional; Jawahir Thontowi

UU No. 32/2004, adalah bukti tentang adanya komitmen pemerintah $\mathrm{Rl}$ terhadap HAM internasional. Akan tetapi, instrumen tersebut tidak dapat secara otomatis diimplementasikan, mengingat hubungan asymetris antara wacana Barat dan Timur tentang HAM, dan tumpang tindih peraturan hukum yang bersifat sektoral masih terus berlangsung. Apakah pemberdayaan komunitas lokal harus dilakukan dengan formalisasi atau bagian dari birokrasi pemerintah daerah tidaklah penting. Lebih penting dari itu adalah bagaimana mereka menyebarkan luaskan nilai-nilai universal melalui institusi lokal dan pemerintah yaitu eksekutif dan legislatif dituntut untuk mewujudkannya dalam berbagai bentuk peraturan daerah dan kebijakan relevan dengan tuntutan masyarakat.

\section{Daftar Pustaka}

Collumbis Theodore,1982, dalam Intemational Relations and Politics.

Goldrick Dominic Mc.1994, The Human Rights Committee: Its Role in the Development of the Intemational Covenant on Civil and Political Rights. Oxford Clarendon Press.

Islamil, Nur Hasan. Otonomi Bidang Pertanahan: Reposisi Peranan Pusat dan Daerah dan Idiologi Politik Pertanahan. Mimbar Hukum No. 34/ IV/2000.

Keesing, Roger M. 1981,Culture, Society, and the Individual, dalam. Culture Anthropology. Canbera: Halt Rinehart and Winston, Inc.
Mudjiono,2004. Eksistensi Hak Ulayat Dalam Pembangunan Daerah. Jumal Hukum No. 26 Vol. It.

Muzaffor Chandra, dalam karyanya tentang HAM dalam wacana Barat dan Tradisi Timur.

Rahardjo, Satjipto,2005, Hak Asasi Manusia Dalam Masyarakatnya. PT.Rafika Aditama.

Robertson A.H. dan J.G.1996, Merill Human Rights in The World An Introduction to the Study of the International Protection of Human Rights. Manchester and New York: University Press.

Slaat, Herman, pengajar Law School Neigmegen University Netherlands. Karyanya tersebut telah diterbitkan menjadi bukum yang diterbitkan di Gama Press.

Steiner, Henry J. dan Philip Alston, 1996. Intemational Human Rights in Context. Oxford, New York: Clarendom University Press.

Thontowi, Jawahir,2000, HAM dan Hukum Internasional dan Prospeknya Dalam Kabinet Persatuan Nasional. Alam Jurnal Magister Hukum. Vol 2. 1. Februari.

Thontowi, Jawahir, 1997,Desertasi, Lawand Custom in Makassar Society. The Interaction of Local Custom and $\mathrm{Na}$ tional Legal System in Dispate ResoIution. Ph.D Thesis, Australia: The University of Western. 